\section{PIOTR ZWIERZCHOWSKI}

Faculty of Humanities

Kazimierz Wielki University, Bydgoszcz
Images

vol. XXIV/no. 33

Poznań 2018

ISSN 1731-45Ox

\title{
The Party in Krzysztof Kieślowski’s Films $^{[1]}$
}

\begin{abstract}
Piotr Zwierzchowski, The Party in Krzysztof Kieślowski's Films. "Images" vol. XXIV, no. 33, Poznań 2018. Adam Mickiewicz University Press. Pp. 137-153. ISSN 1731-450X. DOI 10.14746/i.2018.33.12.

Probably no other Polish filmmaker has devoted as much attention to the Polish United Workers' Party (PZPR) as Krzysztof Kieślowski did in his films. Early on, he perceived the party as an organization where one could meet people with different desires, motivations and modus operandi. Kieślowski's perspective could be defined as such: do not judge the whole, focus on individuals. His subsequent films present a change in this perspective. Workers and devoted members of the communist party were in the center of the director's interest in some of his early films. Later, he focused more and more on individuals, especially those who had to face the party as a structure and hierarchy. Kieślowski's films made in the early 1980s show party leaders and people in charge who eventually turn out to be losers. Kieślowski perceived various aspects and forms of being a party member, not only as a stepping stone for one's career. He saw and presented the everyday life of PZPR, relations between the authorities and society, and its members and representatives of the party apparatus. He was quite critical about the party and people in charge, but also tried to see and present the reasons motivating their conduct. Social and political changes in Poland in the early 1980s made this kind of approach increasingly difficult for Kieślowski.
\end{abstract}

KEYworDs: Krzysztof Kieślowski, Polish cinema, film and politics, images of Polish United Workers' Party

In the autumn of 1981 Kazimierz Karabasz asked five documentarians to write about, among other things, what documentary films could be of interest to contemporary viewers. Based on meetings and conversations, Marcel Łoziński distinguished, the following:

Films about the mechanisms of rule at the highest levels of power (e.g. a film about a meeting of the Political Bureau was demanded). [...]

Film portraits:

- of rebellious people (huge need). [...]

- of former and current representatives of the authorities

[...] Films touching taboo topics.[2]

Similar expectations were indicated by Krystyna Gryczełowska, who wrote that the viewer was interested in both what was currently happening in Poland and accounts about the "settling of accounts"[3]. Adam Zagajewskki and Julian Kornhauser's demand from the previous decade that it was necessary to describe the "unrepresented world" was still valid, especially in regard to the authorities, and for Krzysztof Kieślowski this was one of foundations of his work. In the book The

[1] Part of a larger whole.

[3] Ibidem, p. 36.

[2] K. Karabasz, Bez fikcji - z notatek filmowego doku-

mentalisty, Warszawa 1985, pp. 36-37. 
Unrepresented World (Świat nie przedstawiony, 1974)[4], these two poets demanded the examination of reality unfettered by ideology and propaganda. "If we begin to describe something - as Kieślowski has been saying for many years - we will in a sense bring it to life" [5]; this was the only way such a reality could come into being.

And "If the goal of a Polish filmmaker in the 1970s was to describe reality, this description could not lack the people who decided about the fate of the whole society - the politicians".[6] When speaking about the authorities, due to present circumstances, Kieślowski concentrated above all on the Polish United Workers' Party (Polska Zjednoczona Partia Robotnicza, PZPR). Therefore, he not only analyzed the processes of exercising power, both in relation to individuals and the community, but also described or assessed a quite precisely defined and contextualized situation.

In July of 1977 Andrzej Kijowski noted in his diary:

A decline in the prestige of a social and political activist.

A decline in the prestige of ideology. A decrease in the word's value.

A decline of social values...

A new version of the old individualism: a cunning egoism.[7]

A decline in the prestige of a political activist, especially of a party activist, had of course begun earlier. This included the experiences of 1976: adding the PZPR's leadership and Poland's inviolable union with the Soviet Union to the constitution, the brutal suppression of strikes and protests against price increases, and the worsening economic situation eventually eroded the relationship between the authorities and society. This caesura is also visible in Kieślowski's works, and in his attitude to the party. In the beginning, he perceived it, as he himself spoke of it, as a place where one could encounter people with various desires, motivations and ways of acting. One should not evaluate the whole, but focus on such people. But when we look at his next films Workers 1971: Nothing About Us Without Us (Robotnicy 1971: Nic o nas bez nas, 1972; co-directed by Tomasz Zygadło), Bricklayer (Murarz, 1973), Curriculum Vitae (Źyciorys, 1975), I Don't Know (Nie wiem, 1976); The Scar (Blizna, 1976), Short Working Day (Krótki dzień pracy, 1981), and Blind Chance (Przypadek, 1981)[8] - we notice a change in perspective. In Workers $1971 \ldots$ high-ranking apparatchiks appear, but the director's focus is on workers who still belong to the party and trust it. Later, he focuses more and more on the individual, especially one who

[4] J. Kornhauser, A. Zagajewski, Świat nie przedstawiony, Kraków 1974.

[5] K. Kieślowski, O sobie, ed. D. Stok, Kraków 1997, p. 49.

[6] T. Lubelski, "Od Personelu do Bez końca, czyli siedem faz odwracania kamery”, [in:] Kino Krzysztofa Kieślowskiego, ed. T. Lubelski, Kraków 1997, p. 43.
[7] A. Kijowski, Dziennik 1970-1977, selection and edition of the text by K. Kijowska and J. Błoński, Kraków 1998, p. 394.

[8] Each of these films was not made available for public viewing. The only exception was Curriculum Vitae, but it was distributed in a limited way. Of course, it was not due to the image of the party. It was only a part of the too credible portrayal of contemporary Poland. 
has to face the party structure and hierarchy: on Malesa from Bricklayer, Gralak from Curriculum Vitae, and the plant manager from I Don't Know. This concerns both their relationships with the various party bodies that decide about them and other workers, as well as their own participation in these bodies, as in the case of Malesa. In Blind Chance and Short Working Day we are still dealing with individuals, but ones who already belong to the power apparatus, but, significantly, ones who turn out to be losers. Moreover, in both films during their production, the image of the party's representatives became more and more negative.

The heroes of Workers $1971 \ldots$ go to work, immersed in a world defined by radio and press communications, as well as by slogans posted on the walls. A specific audiovisual noise surrounds the anonymous masses, the working class, building socialism under the bright leadership of Comrade Edward Gierek, First Secretary of the Central Committee of the PZPR, who took power at the end of 1970 in Poland. However, the next shots clearly show that we are not dealing with an imagined working class, but with specific individuals, people with names. The party's care of and harmonious cooperation with workers has also been almost immediately negated. Critical remarks about hard work and low pay do not result in attempts to change things, but in efforts to remove those who complain.

In Workers $1971 \ldots$, in the scene showing an electoral meeting in a large workplace (shipyard?), one managed to show how far the the declared rule of the working class was from the workers, what kind of feudal respect for the power it ensured in them, how aloof from it were those who had recently protested. They were still far from "setting up their own committees" as would happen in 1989.[9]

These workers painfully experienced December of 1970, when over forty people were killed, and over 1100 were injured on the streets of Gdynia, Gdańsk, Szczecin and Elbląg; the army fired on workers striking in protest against an increase in food prices. In the film there is some discussion between the workers and their superiors. But during the meeting at which delegates to the Sixth Congress of the PZPR were to be elected, we watch only a ritual. The fictitiousness of the election is unambiguously suggested, and a debate in the shipyard shows that the workers treat the party more seriously than its higher-ranking representatives. It is not just a game for them. They begin to make demands, and do not allow one of the candidates to leave. They believe that something can be done. The crew's candidate wins. One of the workers says straightforwardly that there is no communication between the party and the workers. But they still have hope; therefore, they begin to talk. In a few years, their hope will be almost gone.

In subsequent films, this discord will grow. Antoni Gralak, the hero of Curriculum Vitae made a few years later, says that "[...] at

[9] T. Sobolewski, “Troska ostateczna. Uwagi o społecznym kontekście kina Krzysztofa Kieślow- skiego", [in:] Kino Krzysztofa Kieślowskiego, op. cit., p. 111. 
present there is too much cooperation between the factory committee and the company's management, but too little cooperation among the workers, with the workers". The head of the factory committee reacts to this, declaring that "for us there is neither the workers' interest nor the management's interest and there can be no such interest, because if there is, you either have to change the management or talk to the workers". In such a situation the party's task is to make these interests converge. It cannot be otherwise in a socialist company. His strong reaction is due to the fact that Gralak has questioned the Party's place in the workplace. Workers $1971 \ldots$ still expresses hope for change, ones related to the politics of everyday life, e.g. that qualifications will be more important than party affiliation (the same theme is found in Bricklayer). They are convinced that Edward Gierek has come to power thanks to the working class' support and are ready to trust him. And it is the theme of trust, above all to the Party, that becomes more and more important in this discussion. One cannot expect, as the interlocutors emphasize, that if people have been time and again disappointed, this would not change anything. These fragments are shown alternately with the image of workers leaving the factory. One has the impression that those who are now engaged in talks will leave the factories and claim their rights after the next disappointment. This not yet the case in Bricklayer, or in Curriculum Vitae, but is already happening in Short Working Day.

Does Kieślowski demonize the authorities in his early films? On the contrary, he de-demonizes them, takes them off the pedestal. Standing aside, being a political outsider, not associated with any faith or ideology (he used to call himself a man without roots) he is fascinated by the psychology of both the party's functionaries and its believers. He conducts a thorough analysis of communism without resentment, assuming the good faith of those involved and watching the crisis of that faith, the decay of an ideal that has not met elementary human longing for living in community, solidarity, social harmony.[10]

Józef Malesa, one of the titular bricklayer's in Kieślowski's film, is aware that his career path was his own choice, though one largely made under the influence of family tradition. He agreed to go to school for activists. He believed in the party's vision but reality turned out to be different than what he had imagined. As he himself says, he wanted to become an activist, but in fact became an official. He resigned after 1956, returned to work as a bricklayer. Mikołaj Jazdon has written that the characters in Curriculum Vitae and I Don't Know, unlike Malesa, "never freely left the party. To the end, they tried to combine their own uncompromising attitude with membership in an organization that did not inherently tolerate a lack of submission". [11] However, it is worth noting that Malesa decides to leave his post in the party apparatus, but not the PZPR itself, at least there is no mention of it. For him, but also

[10] Ibidem, pp. 110-111.

[11] M. Jazdon, Dokumenty Kieślowskiego, Poznań

2002, p. 110. 
for Gralak, membership in the party is something natural, resulting from his beliefs, circumstances and contemporary reality, although with time he becomes more and more disappointed. The hero of I Don't Know, a party member and the manager of the leather factory in Swidnica, fights against corruption in the provincial committee as well, but he has no illusions about the party hierarchy.

In Kieślowski's films, respect for people who believe in the party as both an exponent of certain ideals and a form of social life is constantly present.[12] Yet, the party's internal differentiation becomes more and more visible, and criticism of the party hierarchy and power apparatus grows stronger. After Workers 1971... he wanted to film long interviews with politicians, including Wiesław Gomułka, Józef Cyrankiewicz and Mieczysław Moczar. These were to be their talks, nothing more, no illustration, something like a recording. It is hardly surprising, however, that he did not get permission, even assuming that the material shot would be kept in the archive.[13] Since a visit with a camera to a meeting of the Politburo was impossible, Kieślowski decided to look at the work of one of the party's lower bodies, one closer to the everyday functioning of the party apparatus: the Party Board of Control.

In Curriculum Vitae, made in 1975, Antoni Gralak appears before the Provincial Party Board of Control as he has appealed his expulsion from the party. The protagonist is a fictional character, although his biography was constructed on the basis of authentic documents. The party board, however, is real, and it is to this body that the film is devoted. Curriculum Vitae reveals reality by pointing to the existence and functioning of such a structure in the party as well as by revealing the relationship between the authorities and the ruled, and the a priori attribution of rightness to the former.[14] Nevertheless

through films shot in the 1970s, Kieślowski acted to reduce the distance between the people and the authorities; to reduce distance, not to increase it, to understand, but not to hate. The humanization of power - not revolution.[15]

The apogee of the crisis of trust between the authorities and society is still to come. It still seems that changes can be made within the system.

If you want to reform the party, then you have to say: "You have to reform it, because this and that are wrong in it". But how can I get evidence that this and that are wrong? From a description. No matter what kind of description it would be. Of course, these could be from party reports, party meetings. Or discussions in the press. But there must be some statement of fact, that is, a description. Curriculum Vitae situated itself within exactly such a description. [16]

[12] T. Sobolewski, "Spokój i bunt. Uwagi o twórczości Krzysztofa Kieślowskiego", [in:] Kino polskie $w$ trzynastu sekwencjach, ed. E. Nurczyńska-Fidelska, Kraków 2005, p. 132.
[13] K. Kieślowski, O sobie, op. cit., pp. 164-165. [14] M. Jazdon, Dokumenty Kieślowskiego, op. cit., p. 82.

[15] T. Sobolewski, “Spokój i bunt..., op. cit., p. 132. [16] K. Kieślowski, O sobie, op. cit., p. 51. 
What draws our attention in this quote is not only its reference to a demand to describe reality, but also the belief in the possibility of transforming it. Of course, this was the goal of representatives of the new changes in Polish documentary film. However, what is being referred to is the foundation of the PRL's system of power: the Polish United Workers' Party. Can Curriculum Vitae be seen as a manifestation of political commitment? Kieślowski certainly had no intention of opting for one or the other. In accord with his attitude to the world and people, he assumed that a simple division between "us" and "them" could not be made".[17] He tried to understand the members of the board, why they did what they did, what their reasons were, and whether they did so out of conviction. [18]

Did this idea succeed? It is difficult to answer this question without taking into account the context of the reception. One should also remember that Curriculum Vitae was not the just director's idea. The initiative also came from the party's reformer wing.[19] The idea was to show it from a different perspective, to induce self-reflection, which to some extent happened.[20] It was not without reason, however, that the film aroused controversy during its pre-release screening. Zygmunt Janik from the Central Committee of the PZPR emphasized at the time that "because of its topic the film was not eligible for wide distribution". [21] He recognized, however, that although the committee's opinion was unfavourable, the film itself was suitable to be "the material for discussion about the attitude of the party member".[22] The remaining participants, including Mieczysław Kofta, Ryszard Koniczek and Stefan Czarnecki, praised Curriculum Vitae for its quality journalism, pointing out that it made people think. For Jerzy Eljasiak it was too demagogic, largely presenting the viewpoint of only one side.[23]

However, taking the contemporary viewpoint into account, the party's image is certainly not unambiguous (Gralak also fits this image), and some of the demands, attitudes and behaviours of the board are clearly not right. Nevertheless, as one critic has rightly observed "the anti-party film that Kieślowski made was commissioned by the party".[24] The director deals with one of the mildest party bodies; however, the

[17] Cf. T. Sobolewski, "Świadek życia", [in:]

K. Kieślowski, Przypadek i inne teksty, ed. H. Krall, afterword by T. Sobolewski, Kraków 1998, p. 185.

[18] K. Kieślowski, O sobie, op. cit. p. 52.

[19] S. Zawiśliński, Kieślowski. Ważne, żeby iść..., Izabelin 2005, p. 146; K. Kieślowski, O sobie, op. cit., p. 51.

[20] An example can be a discussion on Curriculum Vitae, which took place during the training course for activists in the Omig factory in Mokotów (M. Radgowski, “Seans”, "Polityka” 1976, no. 7, p. 3). [21] Protokół z posiedzenia Komisji Ocen Artystycznych Filmów Krótkometrażowych $w$ dniu 27.III.75, [in:] Protokoły posiedzeń Komisji Ocen Artystycznych
Filmów. 1975, Archiwum Akt Nowych (AAN), Naczelny Zarząd Kinematografii, Zespół Programu i Rozpowszechniania Filmów, file no. 4/28, f. 1 (122). [22] Ibidem. In the book Film w pracy ideowo-wychowawczej by Jadwiga Łużyńska-Dorobowa published in 1977, Curriculum Vitae was recommended as a reference material for party training courses "in order to specifically emphasize the moral attitude of a party member". J. Łużyńska-Dorobowa, Film w pracy ideowo-wychowawczej, Warszawa 1977, p. 161.

[23] Protokół z posiedzenia Komisji Ocen Artystycznych, op. cit., f. 2 (123).

[24] T. Sobolewski, "Świadek życia”, op. cit., p. 183. 
impression is unambiguous. What matters is not only meetings, not even those of the Party Board of Control, one of the party's structures, but the dominance of institutions over individuals. It is not the individual who decides about his or her life, but the party, which interprets the entire life of a man, both in his public life as a worker and in his private life as a political activist. They assess his or her marriage, his or her attitude to religion. We do not know what they have decided, as the board will decide behind closed doors. Gralak is waiting in the corridor. Nothing depends on him anymore. We see pictures of his whole life, which in themselves will be of no importance if the members of the board so decide.

The absurdity and horror of the situation are emphasized by scarce, contrasting lighting. Only fragments of the face emerge from darkness - the outline of a nose, black eyeholes, a forehead - caught in a stream of light from a hanging lamp. The faces of members of the Party Board of Control are as indistinct as their views, and the weakly-lit face of Gralak resembles the well-known image of Franz Kafka. Thanks to that, the whole situation in the film inevitably carries associations with The Trial (Der Prozeß).[25]

The image of the authorities becomes worse and worse in subsequent films. They do not openly criticize the political system, but show "a process of separation of the authorities from society, the mechanism of their degeneration".[26] Tadeusz Lubelski wrote this about The Scar, but it can also refer to later films. The party authorities exert a destructive or self-destructive influence on everyone, regardless of his or her social status (although one should remember that the highest authorities were out of reach of filmmakers. They had no chance to speak critically of them). Examples of this include the plant manager from I Don't Know, who looses his position and health because of a conflict with dishonest activists; the manager Bednarz who, despite his good intentions, has to endorse the unreasonable political decisions of his superiors; [27] and, above all, the Secretary of the Provincial Party Committee from Short Working Day.

It is worth noting that the history described in I Don't Know is not much different from the plot of Where the Water Is Pure and the Grass Is Green (Gdzie woda czysta i trwa zielona), a film made a year later in the spirit of a party counter-offensive by Bohdan Poręba, a director who was heavily involved in politics and strongly supporting the authorities.[28] In both films, the protagonist is commissioned

[25] M. Jazdon, Dokumenty Kieślowskiego, op. cit., p. 111.

[26] T. Lubelski, “Od Personelu do Bez końca, czyli siedem faz odwracania kamery", op. cit., p. 43.

[27] The Scar is a feature film, but the basis of the whole story was Romuald Karaśs reportage about the chemical factory in Puławy. Bednarz is appointed as the manager of the chemical factory in Olecko, which is to be built at a place unsuitable for this as it will have negative effects on the natural environment and local community. The decision was made without any consultations and factual analyses. It was based was political interests. Bednarz cares about people and public opinion, but he also tries to pursue the authorities's interests. Finally, he turns out to be a double loser: he is increasingly moving away from people, after the events of 1970 he is sent into retirement. [28] Cf. P. Zwierzchowski, "Szeryf z komitetu powiatowego. O wizerunku sekretarza PZPR w kinie polskim lat 70., "Kwartalnik Filmowy" 2015, no. 92; 
by high-ranking party authorities to go to a city or factory to remedy the situation by fighting against local cliques and thievery. Therefore, if one wants to talk about how they differ from each other, it is not in how they diagnose the situation in Poland in the mid-1970s. Nor is it in the differences between a fictional hero and an authentic character, nor the conventions used. In Poręba's films, in a idealized situation the system would be able to purify itself. It only needs the right man, who believing in the idea, will turn to the workers. The hero of I Don't Know loses, but only as a man of the system.[29]

In Short Working Day there is a similar situation, one that is even more expressive. The hero loses both as a man and, to an even greater extent, as a minor, though seemingly prominent, link in the system. Paradoxically, Kieślowski is not interested in the secretary as an individual, but only as a representative of the authorities. The latter did not necessarily mean the party, and being a member of the PZPR was not synonymous with having power. Earlier Kieślowski looked at various relations between people and the party. This time he focuses on showing a failure of the system, first of all, in the people related to it who acquire its characteristics. Therefore, "Short Working Day does not answer existential questions, but only accurately reflects the atmosphere of those days, the official way of thinking".[30]

The director did not like this film. He considered it one of his weakest works. The film also failed because, instead of being an attempt to analyze power, it turned out to be a journalistic accusation of it. Kieślowski wrote that "we did not try hard to enter into the hero's character in the script".[31] The differences between Hanna Krall's reportage, the film adaptation of the novel, the script and the film[32] would rather suggest that this already happened during production. On the one hand, Short Working Day was supposed to be a faithful account of the events of June 25, 1976, when many factories across Poland, including Radom, went on strike to protest drastic price increases. On the other hand, it was a story about a man who, being in a unique situation, has to rethink many things, including the problem of power itself.

In Hanna Krall's novel the protagonist is Janusz Prokopiak, the first secretary of the Provincial Committee of the PZPR and one of the main figures of the June 1976 events, [33] but not in the script or the film (the city is also not defined). Of course, we have no doubts that it is about an authentic character, but this generalization is intentional. The

M. Kunicki, "Heroism, Raison d'état, and National Communism: Red Nationalism in the Cinema of People's Poland", "Contemporary European History" 2012, vol. 21, no. 2, pp. 242-252.

[29] R. Marszałek, "Między dokumentem a fikcją", [in:] Kino Krzysztofa Kieślowskiego, op. cit., p. 16. [30] K. Mąka-Malatyńska, Krall i filmowcy, Poznań 2006, p. 83 .
[31] K. Kieślowski, O sobie, op. cit., p. 90.

[32] They are analysed in detaild by K. Mąka-Malatyńska (Krall i filmowcy, op. cit., pp. 77-85). [33] See: J. Prokopiak, Radomski czerwiec '76. Wspomnienia partyjnego sekretarza, Warszawa, Radom 2001; P. Sasanka, Czerwiec 1976. Geneza przebieg - konsekwencje, Warszawa 2017 (chapter: 25 czerwca). 
point was not only to reconstruct the events, but also to say something about a man of power in a specific situation. Accustomed to typical, ritualistic behaviour, strong with the "party's power", but now lonely, surrounded, and closed inside the committee's seemingly safe rooms, the party secretary now has to face the protesting crowd.

The workers are essentially right. The truth is on their side. When the crowd comes into play, however, the truth undergoes a certain deformation, it loses its moral strength. The domain of the crowd is chaos and destruction. The director's favour is always directed towards individuals, even if they are party secretaries, third-rate activists. [34]

Tadeusz Lubelski wrote about this reflective liking for the hero of Short Working Day, who is being watched in a place inaccessible to the viewer and besieged by the crowd, but the critic at the same time noticed that this affinity was neutralized both by the secretary's behaviour and unconvincing acting. On the other hand, Wacław Ulewicz, who played the role of a party secretary in Dignity (Godność, 1984) and Time For Hope (Czas nadziei, 1986) by Roman Wionczek, and of a party activist in Four-Star Hotel (Hotel klasy Lux, 1979) by Ryszard Ber[35], purposely creates such an image of the party's representative: colourless, devoid of any charisma, whose authority it turns out is only apparent, and merely results from his position in the party hierarchy and ability to fit into its rituals. In fact, this time Kieślowski does not want to or cannot understand his hero. This is particularly evident when we compare the film with the original idea.

In the film Janusz is a static character, and it is not only the actor who is to blame for this. Initially, on "having received an intensive social education",[36] the party secretary was to be someone other than a man who began his working day at $6 \mathrm{am}$. It was already visible in the script how this special day changes the hero. He began to treat his co-workers differently, such as, the driver Henio who undergoes an emotional shock. He treats him cordially, takes his hand "[...] it may be the first, really normal, sympathetic gesture of the secretary we see on the screen [...]".[37] In the film he is nice to the driver already earlier, but he now takes Henio to the room where he is awaited by a member of the party executive organ, who was previously injured by demonstrators, but in him you can hardly see any concern for his co-workers. A moment later, he is on the phone, and according to the script, "for the first time since his talks to Warsaw, the tone of a disciplined party member disappears in his voice and there appears a slight

[34] M. Kornatowska, “Sceny z Kieślowskiego. Krótki dzień pracy", "Film" 1996, no. 5, p. 117.

[35] He also appeared in Where the Water Is Pure and the Grass Is Green by Poręba and Fly High (Wysokie loty, 1978, prem. 1980) by Ryszard Filipski. See: M. Haltof, The Cinema of Krzysztof Kieślowski. Variations on destiny and chance, London, New York 2004, pp. 51-52.
[36] H. Krall, “[Film's Novella]”, [in:] Krótki dzień pracy. 1. Nowela filmowa; 2. Temat filmu, Archiwum Filmoteki Narodowej - Instytutu Audiowizualnego, file no S-30041.

[37] H. Krall, K. Kieślowski, "Widok z okna na I piętrze (Scenariusz filmu TV, 3 odcinki)", Warszawa 1981, [in:] Krótki dzień pracy. Scenariusz filmu fabularnego, Archiwum FINA, file no. S-30041, f. 27. 
fury of a man who is already beginning to know more than people on the other side of the telephone line)".[38] There is no such impression in the talks shown in the film. Moreover, in the script the hero refuses to leave the committee building because "(it seems that the secretary has to some extent been affected by the atmosphere of rebellion, and so he begins to talk to Warsaw as a man from HERE)".[39] Again, the film definitely lacks this nuance.[40]

In the script, and earlier in Krall's reportage, the secretary mentions men who wanted to throw him out of a window:

But it wasn't me personally they wanted to throw out. I was a synonym for power to them, and it was this that they wanted to throw out. They are fed up not with me, but only with us - I've comforted myself, but I don't know which thought has been worse.

How is it that we as a nation give birth to so eminent people - Curie-Skłodowska, Wojtyła, Miłosz. ... No, I wouldn’t think so. Out of the last two, the former wasn't yet Pope and the other was a Nobel laureate. Anyway, now I think: such outstanding individuals come from our nation, but we ourselves aren't able to give birth to eminent authorities.[41]

The protagonist wonders about the reasons for this being so. Is it the result of war and the destruction of the intelligentsia? He also wonders about who he would be himself, "if our society gave birth to such a government that it is really able to".[42] At this moment one can see a plot very similar to Bricklayer. The party secretary was an expert at building, so he would probably be a good manager of a company. Józef Malesa was a good bricklayer, but at some time, although under the specific circumstances of the first half of the 1950s, he went to work in the apparatus of a youth organization. He felt bad there. He felt better when he returned to his first occupation. The secretary from the script is Malesa, who has not resigned. According to Mikołaj Jazdon, Bricklayer, Curriculum Vitae, and I Don't Know form a trilogy whose heroes are men connected at some point with the party. They try to live honestly, in accordance with their own rules, but they are prevented from doing so by the totalitarian system. [43] If Short Working Day had been made according to the original idea, it might have been a little more complex, above all because of the secretary's function. It would have been an element of this trilogy or rather a specific commentary on it.

[38] Ibidem.

[39] Ibidem, f. 28.

[40] Of course, the script also includes fragments in which the hero is judged very negatively. In the end, when the secretary leaves, we see his face: "it is a fierce face, of a man being rather internally enraged than afraid. Enraged by the first true misfortune that happened to him [sic in the text - PZ] in his life...". Ibidem, f. 41.

[41] H. Krall, K. Kieślowski, Widok z okna na I piętrze..., op. cit., p. 30.
[42] Ibidem.

[43] M. Jazdon, Dokumenty Kieślowskiego, op. cit., p. 108. As far as Bricklayer is concerned this opinion appears too far-reaching. Józef Malesa resigned from his career as a party activist, discovering growing discrepancies between ideas and reality. There is bitterness in his voice, but also satisfaction felt by someone who was able to make a decision at the right moment, and later he performed his work well and enjoyed it for many years. His colleagues achieved the highest social positions, he was building Warsaw. 
These issues look different in the film. Initiated by the thought of how they wanted to throw him out of the window, they concern one's position within the structure of power, but not power itself. The secretary excuses himself, but at the same time reveals his hypocrisy: he himself knows that what he does and what he thinks are two different things. He is not interested in solving the problem, but in what will happen to him (he also does not feel any connection with his superiors, but rather Schadenfreunde at the thought of what would happen to those placed higher up in the hierarchy if the people began to settle accounts with them). Katarzyna Mąka-Malatyńska is probably right in her analysis of the secretary's emotions; she sees nervousness and fear in his face, not "cynicism", which is proven by his internal monologue. "I think", she writes, "that this paradox is not an attempt to defend the hero, but rather emphasizes the schematicness of his thinking".[44]

Another problem is his inability to go beyond routine and ritual. In Curriculum Vitae the members of the Board of Control do not deny that Gralak is right. However, they emphasize the impropriety of his behaviour, which went beyond the ritual allowed by the party. The following is said twice emphatically: "A member of the party cannot say that". This occurs when Gralak says that people do not want to tell the truth at meetings because it can cause harm to them (this issue also occurs in Workers $1971 \ldots$ and The Scar). In this way, it destroys the credibility of his official performance, it negates a ritual. The rituality of party life, or more broadly, public life, is visible in many films. In Workers $1971 \ldots$ it is seen in meetings, in Bricklayer it is seen in the May Day parade, and in Curriculum Vitae it is embodied in the meetings of the Board. The protagonist of Short Working Day, for whom being a member of the party is largely based on participation in rituals, as is clearly shown at the beginning of the film, is excluded from them. When a certain conventionality or theatricality is replaced by social reality, he cannot fit in.[45] He does not know how to act, but in the script his helplessness in the face of his own situation is presented in a much more interesting way, not only with regard to the present moment, but also in the context of his entire life. The party was the essence of his life. Can he then agree with the protesting people? "I - a representative of the authorities, a disciplined member of the party?".[46]

Such helplessness is a terrible thing. Man is not used to it. Throughout life everything is as it should be, and man understands everything, and man knows how to move, and here it is completely falling apart - and what now?[47]

In the film we deal with a party representative who is outside of society, who feels anxiety and contempt for it, who is focused on his

[44] K. Mąka-Malatyńska, Krall i filmowcy, op. cit., p. 80 .

[45] M. Kornatowska, "Sceny z Kieślowskiego", op. cit., p. 116.
[46] H. Krall, K. Kieślowski, Widok z okna na I piętrze..., op. cit., p. 20.

[47] Ibidem, p. 19. 
own situation, but unable to think deeply about it. In the reportage and the novel, the problem of the individual's responsibility for power was not only clear from the point of view of an external observer, but also realized by the party secretary.

Previously he has held various responsible positions - in the building industry, trade unions, very responsible ones, but this was different. It is difficult to say what the difference is because it is not the responsibility at all. It is more likely to be the ceremonies, the nomination of the one who represents power. There, one speaks matter-of-factly. Here, one begins with enumerating titles - a Member of the Central Committee will take the floor - a Member of Parliament - Chairman of the Voivodship National Council - Secretary of the Voivodship Committee - how many there are of these functions, each being so important and unavailable to anyone sitting in the hall - and only at the end is the surname said. And now the moment of applause comes, everyone is smiling, the secretary does not of course prolong the ovation; he speaks in a matter-of-fact manner, but every opinion he makes about the case is considered to be a decision. In short - one can state objectively that a lot of psychological resilience is needed not to wallow in all this ... Has the secretary wallowed? - he has asked himself the next question [...].[48]

But he did not manage: he performed his function for only thirteen months. But in the film the secretary's reflection - if one call it that - is different, much more unambiguous, and is essentially his self-unmasking.[49] In his mind he curses the inhabitants of the city for not being able to appreciate what he did for them for those thirteen months. Bastards. But he does not feel offended. "An activist cannot be offended by the working class, even if the working class makes mistakes". In fact, we are dealing here with the arrogance of the authorities, who put themselves above society. In Krall, but also in the script, the protagonist tries to come to an agreement. At the beginning he cannot understand why he fails. He is only beginning to see that the situation has completely changed. Of course, he tries to follow the best practices. He would like to bring party activists so that they would - not using violence - ease tensions. Like Gralak in The Calm (Spokój, 1976, prem. 1980) and Mosz in Camera Buff (Amator, 1979) "he wants to get along well with everyone, be on both sides of the conflict at the same time". [50]

The film, whose editing Kieślowski finished just before the imposition of martial law, is definitely more critical of the secretary than the reportage, the novella or the script. And its ending, which was present in previous projects, including shots from rallies and protests, images of punished people from the demonstrations, photos from the "August agreements", clearly shows the defeat of the party and its representatives, of which most important harbingers appeared in 1976. Kieślowski was

[48] H. Krall, "Widok z okna na I piętrze (Nowela filmowa fabularnego filmu telewizyjnego - trzy odcinki)", p. 1, [in:] Krótki dzień pracy. 1. Nowela filmowa; 2. Temat filmu..., p. 12. See also: eadem, Widok z okna na I piętrze, [in:] eadem, Trudności ze wstawaniem. Okna, Warszawa 1990, p. 50.
[49] See: K. Mąka-Malatyńska, Krall i filmowcy, op. cit., p. 80.

[50] T. Lubelski, “Od Personelu do Bez końca...”, op. cit., p. 45. 
undoubtedly fascinated by the problem of power, more and more so over time; Short Working Day was a result of this, but instead of an attempt at a multi-dimensional analysis of its mechanisms and representatives, there appeared only a one-dimensional accusatory portrait of one of them. This was due to both the atmosphere of those years as well as the director's attitude. He was aware of that.

At that time - and today even more - there was no way you could have a desire to understand the party secretary. The party secretary was always considered a man of power, mostly a fool. This one was not him. I did a critical film about him. While doing this film, I was trapped by the milieu's opinion. An inhuman opinion. I did not want to, or maybe I could not really get deep into his heart or soul. I felt a little embarrassed. How is it? To get into the secretary's soul? You can do it with the soul of a priest or a young woman, but of the party secretary? This would not be elegant. Therefore, this character has to become a little schematic. It has not been deepened. I think that today it would not be possible at all to make a deepened film about the first secretary.[51]

In the same year, 1981, Blind Chance was made. In the first of three variants of Witek Długosz's life, Kieślowski presented not only people who, sometimes too much, make use of their power, but also those who are associated with power. Yet, they try to maintain their own sense of dignity. The question was therefore asked of how to reconcile the individual system of values with membership in an organization that excluded individuality. Witek is also such an activist. Kieślowski took his faith and commitment seriously, just as he did in the case of Malesa or Gralak. [52] Being at the starting point and taking into account the socio-political conditions, the hero, regardless of his own beliefs and attitudes, has only two possibilities. Apart from the old party member, devoted to the idea but honest, we watch young cynical activists deprived of any scruples. It is not without reason, however, that both Tadeusz Lubelski and Katarzyna Mąka-Malatyńska point to the functionalization of opposing Werner to Adam, a lost idealist to a cynical careerist.[53] Because of this, the opposing paths that appeared before Witek were clearly outlined in this variant. It is worth noting, however, that both of them actually led to a loss.

Holding onto Werner, Witek would be doomed to stay at the margins, but he is also too honest to accept Adam's attitude. Neither could the viewer do it, nor understand. Originally, however, this figure was delineated differently, more subtly. This is evident, for example, in the scene of the quiet conversation between the three of them, not included in the film, after Czuszka is arrested. Katarzyna Mąka-Malatyńska is right noting that the scene was definitely more literary and emotionally weaker than the film's drastic meeting between the hero and Adam, who slaps Witek and throws him out of

[51] K. Kieślowski, O sobie, op. cit., p. 90.

[52] T. Sobolewski, “Spokój i bunt...”, op. cit., p. 132.
[53] T. Lubelski, "Od Personelu do Bez końca...", op. cit., p. 45; K. Mąka-Malatyńska, Krall i filmowcy, op. cit., p. 52. 
the building.[54] More significant is the less negative image of Adam included in it. In turn, Werner was characterized more ambiguously. Also different is the relationship between him and Werner, which can be seen especially in the story of the release of the young oppositionists. According to Adam, Werner likes neither those for whom he came to stand up nor the authorities' representatives. He stands by, but how to judge this? He believes, but he does not want to have anything to do with it. He has become disappointed. Once, when he had been arrested in the Stalinist era, he was convinced that their activities made sense, "that it is for something". And Adam responds:

Adam: Because this is for something. We've created this world, our generation, as it is, with evil and good. And with rules and laws. [...] If I want to change this bad thing, I have to be inside and obey the rules, even in order to change them.

Werner: I can see how you change.

Adam: Why are telling these guys about faith and hope? You know exactly how attractive you are - burned out by what you believe in and still believing $[\ldots]$

Werner: I'm just saying what I think. And he listened because he was looking for something.

Adam: He wanted to do something. And he did some useful things during these years.

Werner: By your methods.

Adam: No, by his own methods. And he has managed to understand that to arrange the world more justly, you have to do it. And that it costs every time.[55]

What draws our attention here is the self-awareness of the interlocutors, the sense of responsibility, the belief that despite numerous limitations, sometimes something good can be done, and the opposition of Adam to Werner is not so strong as in the film. One can see rather the nuances of the attitudes in the power apparatus (because even though Werner voluntarily found himself at the margins, he is not completely excluded from its privileges). Interestingly, both characters refer to the cinema of moral concern and the cinema of "settling accounts" of the 1960 s in an interesting way. In this version, Adam is quite like Jakub Szelestowski from Camouflage (Barwy ochronne, 1976, prem. 1977) by Krzysztof Zanussi, combining cynicism with bitter wisdom. Zbigniew Zapasiewicz performed in both these roles, strengthening this similarity even more. The filmic character of Adam was not delineated so clearly, however.[56] In turn, Werner, whose model was Szczęsny Dobrowolski[57], recalls another figure performed once by Tadeusz

[54] K. Mąka-Malatyńska, Krall i filmowcy, op. cit., pp. 51-52.

[55] K. Pakulski, K. Kieślowski, Przypadek. Scenopis filmu fabularnego, Archiwum FINA, file no. S-27672, f. $57-58$.
[56] K. Mąka-Malatyńska, Krall i filmowcy, op. cit., p. 52 .

[57] Interestingly, Dobrowolski was also one of the inspirations for Szczęsny from A Souvenir from the Cellulose Mill (Pamiątka $z$ Celulozy, 1952) by Igor 
Łomnicki - secretary Jakuszyn from Life Once More (Życie raz jeszcze, 1964) by Janusz Morgenstern, who believed in his party despite all the bad things that happened to him because of it.

Interestingly, initially Werner, thanks to whom Witek associates himself with the communists, is absent in the script. Długosz becomes a member of the party's youth organization owing to his work on tennis courts and his openness to young people. One can see a similar faith as in Workers 1971..., maybe even in Curriculum Vitae - that there are people for whom the party is not only a place of promotion or political competition, but a place where you can do something good, regardless of barriers.

He was not so naive as not to know that all things happening were perfectly right, that the main course of the organization's activities was not always consistent with the ideas for which it was created, but he often noted with satisfaction that something had been done and stood, that some matter had been settled and people were living in a better way. In all these activities he felt the strength of the party apparatus and the pressure of the mass of people who - and he deeply believed in it - came here not for dancing and holidays and not because of the prospect of a career or just quietness, but what made them come was the belief in the sense of action for improvement and for good things. When he talked about it to Staszek or his uncle - a sports president, he saw in their eyes a smile just over his naiveté and enthusiasm, but he could also see growing respect.[58]

In the film one cannot see it any more. Witek becomes a member of the youth organization on Werner's recommendation. He focuses on administrative and bureaucratic activities, and when he goes to an addiction treatment centre, he goes there not as a youth expert [59], but cynically manoeuvred by more experienced colleagues who do not want to become involved themselves. His good or even noble intentions turn against him. In a world in which an alternative is a voluntary exile or cynicism, Witek must lose. However, it is hard to resist the impression that this conflict is too simple and unambiguous, just like the picture of authorities presented finally in the film.

It is worth remembering, however, that Witek from the second variant, an "oppositional" one, also fails. Kieślowski criticized not only the authorities.

In the mystified reality, real divisions and differences have blurred. Magma has been made. The "regime" people are separated from the "opposition"

Newerly and based on it Cellulose Mill (Celuloza, 1953, prem. 1954) and Under the Phrygian Star (Pod gwiazda frygijska, 1954) by Jerzy Kawalerowicz, all them taking place before the war. The novel and both films, telling about the way of a young worker to the Communist party and the revolutionary movement, are among the most representative of and at the same time the best achievemensts of socialist realism in Poland.
[58] K. Kieślowski, "Przypadek (scenariusz filmu fabularnego)", Warszawa 1980, [in:] idem, Przypadek. Film fabularny. Scenariusz, Archiwum FINA, file no. S-24713, f. 31.

[59] K. Kieślowski, Przypadek, [in:] idem, Przypadek $i$ inne teksty, op. cit., p. 158. 
people only by one step. Often an accidental one. Kieślowski noticed this, among others, in Blind Chance. This instability, obscurity, ambiguity of attitudes, devoid of clearly formulated motivations, helplessness in the face of requirements posed by the current reality were shown by him in No End (Bez konca, 1984, prem. 1985). Beginning with The Scar, he emphasized the danger of amateurism on both the ruling and the ruled sides.[60]

Probably no other Polish filmmaker has devoted so much attention to the party and its representatives. It was too important an element of the authorities and everyday life of Poles so that one could describe the reality of the 1970 and the early years of the next decade without considering its presence. Krzysztof Kieślowski tried to see various aspects and forms of its existence, its everyday life, looking for a career in it, the relationship between the authorities and society. He saw ordinary members and representatives of the party apparatus in it. He was critical of the authorities and the party, but also tried to see their reasons. This was also appreciated by the party itself. An example is the opinion made of him by the Culture Department of the Central Committee:

In the years 1980 to 1981 he was one of the leading initiators of ideologically and organizationally destructive activities of the group of documentary directors. However, what is characteristic of him is that he fights openly. He says officially what he blames the authorities for. He accepts the reasons of the other side.[61]

Blind Chance and Short Working Day show that the latter was more and more difficult for him.

B I B L I O GR A P H Y

Haltof M., The Cinema of Krzysztof Kieślowski. Variations on destiny and chance, London-New York 2004

Jazdon M., Dokumenty Kieślowskiego, Poznań 2002

Karabasz K., Bez fikcji - z notatek filmowego dokumentalisty, Warszawa 1985

Kieślowski K., O sobie, ed. D. Stok, Kraków 1997

Kijowski A., Dziennik 1970-1977, eds. K. Kijowska and J. Błoński, Kraków 1998

Kornatowska M., "Sceny z Kieślowskiego. Krótki dzień pracy", "Film" 1996, no. 5

Kornatowska M., Wodzireje i amatorzy, Warszawa 1990

Kornhauser J., Zagajewski A., Świat nie przedstawiony, Kraków 1974

Krall H., "Widok z okna na I piętrze”, [in:] eadem, Trudności ze wstawaniem. Okna, Warszawa 1990

Kunicki M., "Heroism, Raison détat, and National Communism: Red Nationalism in the Cinema of People's Poland", "Contemporary European History" 2012, vol. 21 , issue 2

Lubelski T., "Od Personelu do Bez końca, czyli siedem faz odwracania kamery”, [in:] Kino Krzysztofa Kieślowskiego, ed. T. Lubelski, Kraków 1997

[60] M. Kornatowska, Wodzireje i amatorzy, Warszawa 1990, p. 174.
[61] Bezpartyjni filmowcy na spotkaniu z przedstawicielami kierownictwa partii, AAN, Polska Zjednoczona Partia Robotnicza, Komitet Centralny, Wydział Kultury, file no. LVI - 1712, f. 5-6. 
Łużyńska-Dorobowa J., Film w pracy ideowo-wychowawczej, Warszawa 1977

Mąka-Malatyńska K., Krall i filmowcy, Poznań 2006

Marszałek R., "Między dokumentem a fikcją", [in:] Kino Krzysztofa Kieślowskiego, ed. T. Lubelski, Kraków 1997

Prokopiak J., Radomski czerwiec '76. Wspomnienia partyjnego sekretarza, Warszawa-Radom 2001

Radgowski M., "Seans", "Polityka” 1976, no. 7

Sasanka P., Czerwiec 1976. Geneza - przebieg - konsekwencje, Warszawa 2017

Sobolewski T., "Spokój i bunt. Uwagi o twórczości Krzysztofa Kieślowskiego", [in:] Kino polskie w trzynastu sekwencjach, ed. E. Nurczyńska-Fidelska, Kraków 2005

Sobolewski T., "Świadek życia", [in:] K. Kieślowski, Przypadek i inne teksty, ed. H. Krall, afterword T. Sobolewski, Kraków 1998

Sobolewski T., "Troska ostateczna. Uwagi o społecznym kontekście kina Krzysztofa Kieślowskiego", [in:] Kino Krzysztofa Kieślowskiego, ed. T. Lubelski, Kraków 1997

Zawiśliński S., Kieślowski. Ważne, żeby iść..., Izabelin 2005

Zwierzchowski P., "Szeryf z komitetu powiatowego. O wizerunku sekretarza PZPR w kinie polskim lat 70.", "Kwartalnik Filmowy" 2015, no. 92

\section{Archival materials}

Bezpartyjni filmowcy na spotkanie z przedstawicielami kierownictwa partii, Archiwum Akt Nowych, Polska Zjednoczona Partia Robotnicza, Komitet Centralny, Wydział Kultury, sygn. LVI - 1712

Kieślowski K., "Przypadek (scenariusz filmu fabularnego)”, Warszawa 1980, [in:] Przypadek. Film fabularny. Scenariusz, Archiwum Filmoteki Narodowej - Instytutu Audiowizualnego, sygn. S-24713

Krall H., "[Nowela filmu]", [in:] Krótki dzień pracy. 1. Nowela filmowa; 2. Temat filmu, Archiwum Filmoteki Narodowej - Instytutu Audiowizualnego, sygn. S-30041

Krall H., Kieślowski K., "Widok z okna na I piętrze (Scenariusz filmu TV, 3 odcinki)", Warszawa 1981, [in:] Krótki dzień pracy. Scenariusz filmu fabularnego, Archiwum Filmoteki Narodowej - Instytutu Audiowizualnego, sygn. S-30041, k. 27

Krall H., "Widok z okna na I piętrze (Nowela filmowa fabularnego filmu telewizyjnego - trzy odcinki)", k. 1, [in:] Krótki dzień pracy. 1. Nowela filmowa; 2. Temat filmu, Archiwum Filmoteki Narodowej - Instytutu Audiowizualnego, sygn. S-30041

Pakulski K., Kieślowski K., Przypadek. Scenopis filmu fabularnego, Archiwum Filmoteki Narodowej - Instytutu Audiowizualnego, sygn. S-27672

"Protokół z posiedzenia Komisji Ocen Artystycznych Filmów Krótkometrażowych w dniu 27.III.75", [in:] Protokoły posiedzeń Komisji Ocen Artystycznych Filmów. 1975, Archiwum Akt Nowych, zespół Naczelnego Zarządu Kinematografii, Zespół Programu i Rozpowszechniania Filmów, sygn. 4/28 